\title{
Do managers at two hierarchical levels differ in how they assess their company's market orientation?*
}

\author{
Mateja Bodlaj
}

The purpose of the presented empirical study was to examine the cultural and behavioural adoption of a market orientation as perceived by two groups of managers: general managers and marketing managers. With regard to marketoriented behaviours, a distinction is made between a responsive and a proactive market orientation. Based on a single-informant approach, comparisons between both groups of managers are made by testing invariant latent mean structures. An analysis of 363 companies from a South-east European country reveals that the general managers perceived all components of a market orientation significantly better than the marketing managers.

Der Zweck dieser empirischen Studie ist es, die kulturelle und verhaltensmäßige Aneignung einer Marktorientierung durch zwei Gruppen von Managern (Geschäftsführer und Marketing-Manager) zu untersuchen. Im Hinblick auf marktorientierte Verhaltensweisen unterscheidet man zwischen einer reaktiven und einer proaktiven Marktorientierung. Basierend auf einem Ein-InformantenAnsatz, wurden Vergleiche angestellt zwischen beiden Gruppen von Managern durch das Testen invariant latenter Mittelwert-Strukturen. Eine Analyse von 363 Unternehmen aus einem südosteuropäischen Land zeigt, dass die Geschäftsführer alle Komponenten einer Orientierung am Markt signifikant besser wahrnehmen als die Marketing-Manager.

Key words: market-oriented culture, market information, responsive and proactive market orientation

Manuscript received: 09.07.11, accepted: 27.03 .12 (2 revisions)

** Mateja Bodlaj, Ph. D., Teaching Assistant, University of Ljubljana, Faculty of Economics, Slovenia. Main research areas: Market orientation and Innovation. Corresponding address: mateja.bodlaj@ef.uni-lj.si 


\section{Introduction}

The market orientation concept is central to marketing thinking and increasingly important in other fields such as strategic management (Gebhardt et al. 2006). Meta-analyses (e.g. Kirca et al. 2005; Ellis 2006) confirm a positive relationship between a market orientation and business performance. However, most companies do not embrace the market orientation concept until they are driven to it by circumstances such as a sales decline, slow sales growth, changing buying patterns, increasing competition or poor results achieved from marketing expenditures (Kotler 2003). Although a market orientation is viewed as an appropriate business philosophy, companies find it difficult to implement it (Gummesson 1991; Day 1999; Mason/Harris 2005; Van Raiij/Stoelhorst 2008).

Managers' perceptions of their company's market orientation effect managerial decision-making. If managers believe their company is highly market-oriented they might do little or nothing to improve their company's market orientation (e.g. Deshpande et al. 1993) because they may consider that the current level of market orientation is sufficient. On the contrary, if managers perceive their company is not market-oriented enough they might raise the company's efforts to increase the market orientation. This study explores whether managers at two hierarchical levels differ in their assessments of their company's market orientation. More specifically, we examine the adoption of market orientation as perceived by general managers and marketing managers. This issue is particularly relevant because these two groups of managers must take the lead with regard to broadening the acceptance of a market orientation within the organisation (e.g. Nakata 2002).

Transitional economies are particularly suited to the investigation of managers' perceptions of market orientation since market orientation is still in its infancy there (cf. Catana/Catana 2004; Menguc/Auh 2006). Creating a market-oriented organisation is essentially a process of cultural transformation (Gebhardt et al. 2006) which requires time and continuing efforts that are not immediately rewarding (Harris 2002; Nakata 2002). Hence, firms in transitional economies are expected to encounter greater difficulties in developing a market orientation than their Western counterparts because the transition from socialism to a market economy has required a fundamental change in managerial attitudes (Ennew et al. 1993). However, only a few empirical studies have investigated the development of a market orientation in transitional economies (e.g. Ennew et al. 1993; Golden et al. 1995; Akimova 2000; Hooley et al. 2000).

This study focuses on Slovenia, a small transitional economy in South-east Europe. The selected country is worthwhile examining because it is not a typical ex-socialist economy. Due to its relative openness towards the West even prior to the transition period, Slovenian firms were in a better position when it came to adopting a market orientation than firms in other European transitional 
economies. In contrast, due to the very small domestic market along with the loss of former Yugoslav markets in 1991 firms had no other option than to start thinking and acting in a more market-oriented way in order to find new markets and survive.

To date, only a few empirical studies have examined the congruence of different key informants' responses within the organisation (e.g. Jaworski/Kohli 1993; Pelham 1997). None of these studies has drawn a distinction between a responsive and a proactive market orientation. In addition, the existing market orientation scales focus on the behavioural perspective. The purpose of this paper is to fill this void in the literature and contribute to the existing knowledge by comparing assessments of the company's market orientation between general managers and marketing managers. Based on data obtained from 363 Slovenian companies, a comparison will be made by distinguishing between: (1) a cultural and a behavioural perspective on market orientation; and 2) a responsive and a proactive market orientation. It should be noted that our study is based on a single-informant approach. However, given the informants' function within the company the sample structure allows us to compare the responses of managers at two hierarchical levels.

The rest of the paper is organised in four sections. In the first section, we provide a literature review of market orientation. In the second section, we explain the research methodology, with the results of the study following in the third section. We conclude with a discussion of the results along with the contributions of the presented empirical study to the market orientation literature, research limitations, and suggestions for future research.

\section{Literature review}

A market orientation is one of the alternative business orientations that emerged in the mid-1950s and emphasises the need to create, deliver and communicate superior customer value more effectively than the competitors in order to achieve business goals (Kotler 2003). Since market-oriented companies focus on customer needs, market orientation is classified as an "open" business orientation in contrast to "closed" business orientations which are characterised by a »make-and-sell« philosophy and concentrate on internal processes rather than customer needs (Snoj et al. 2004). The closed types most often mentioned in the literature are product, production and selling orientation (Snoj/Gabrijan 1998). Product-oriented companies often trust that their engineers can design exceptional products; they get little or no customer input. Production-oriented companies assume that consumers are primarily interested in product availability and low prices. Selling-oriented companies assume that consumers typically show buying inertia and must be coaxed into buying (Kotler 2003).

Some authors (e.g. Gummesson 1991; Golden et al. 1995) use the term "marketing orientation" in order to embrace the same meaning as the "market 
orientation" concept. However, the term "market orientation" is more appropriate because it focuses attention on markets, clarifies that the construct is not exclusively a concern of the marketing function and does not inflate the importance of the marketing function in the firm (Kohli/Jaworski 1990).

A market orientation positively affects various measures of performance, like overall businesses performance, financial performance (e.g. profits, sales), market performance (e.g. market share, perceived quality, customer loyalty, customer satisfaction) and innovation (e.g. innovativeness, new product performance) (Kirca et al. 2005). It contributes to the creation of positional advantage (Hult/Ketchen 2001) as well as positively impacts performance through organisational responsiveness (Hult et al. 2005), innovativeness (Hurley/Hult 1998) and learning orientation (Slater/Narver 1995).

\section{Different perspectives on market orientation}

In general, two perspectives on market orientation prevail in the literature: a cultural perspective (e.g. Narver/Slater 1990; Deshpande et al. 1993) and a behavioural perspective (e.g. Kohli/Jaworski 1990). The cultural perspective relates to more fundamental characteristics of the organisation (Homburg/ Pflesser 2000) such as the organisational culture which emphasises superior customer value as the key value (Narver/Slater 1990; Narver et al. 1998) and placing customer interests first (Deshpande et al. 1993). The behavioural perspective, on the other hand, relates to specific behaviours or activities such as the generation and dissemination of market intelligence and company responsiveness to it (e.g. Kohli/Jaworski 1990). However, in spite of the different perspectives the two most recognised measures of market orientation, i.e. the MARKOR scale (Kohli et al. 1993) and the MKTOR scale (Narver/ Slater 1990), focus on the behavioural perspective. Thus, the cultural perspective has had a stronger impact on the definition than on the development of measures of market orientation (Homburg/Pflesser 2000). According to the literature, the pattern of shared values and beliefs helps individuals understand organisational functioning and thus provides them with norms for behaviour (Deshpande et al. 1993); it is therefore important to understand market orientation first and foremost as an organisational culture in which all employees are committed to the continuous creation of superior value for customers (e.g. Narver/Slater 1990). Despande et al. (1993) view market orientation as being part of an overall, but much more fundamental, corporate culture. Although a stronger market orientation is expected in competitive and innovative organisational cultures, Deshpande et al. (1993) find no such relationships, suggesting that a relatively good market orientation appears to be achievable in a variety of corporate cultures. By contrast, Conrad (1999) reports a higher level of market orientation in companies with a more innovative organisational culture. Gebhardt et al. (2006) also find a correlation between a market orientation and a firm's culture: the latter was in less market-oriented 
companies characterised by a bureaucratic and internal focus; a reliance on historically successful approaches to solve new problems; highly structured routines; employees identifying more with their function, job class or other subgroup than with the overall organisation; a lack of a common understanding of the firm's objectives and strategies etc.

In addition to a cultural and a behavioural perspective, the market orientation literature has in recent years stressed the need to distinguish between two forms of market orientation: responsive and proactive (e.g. Narver et al. 2004; Atuahene-Gima et al. 2005; Tsai et al. 2008; Voola/O'Cass 2010). While a responsive market orientation refers to discovering, understanding and satisfying expressed customer needs, a proactive market orientation refers to discovering, understanding and satisfying latent customer needs (Narver et al. 2004). Responsive market-oriented behaviours with their focus on the company's current knowledge and experience reflect exploitation or adaptive learning. By contrast, proactive market-oriented behaviours with their focus on exploring new knowledge and markets significantly distant from existing experience reflect exploration or generative learning (Slater/Narver 1998; Atuahene-Gima et al. 2005).

Companies need to develop both forms of market orientation simultaneously in order to remain successful over a long period of time (Sheth/Sisodia 1999; Day 1999). Moreover, a responsive market orientation is typically short-term in focus and may be successful only in relatively predictable environments. In a dynamic environment, however, a responsive market orientation will rarely lead to a competitive advantage since it provides an insufficient incentive for radical innovations (Slater/Narver 1998) and creates no new insights into opportunities for delivering superior customer value (Narver et al. 2004).

To date, virtually all empirical studies have focused on the responsive market orientation (Narver et al. 2004) with only a few empirical studies having adopted both forms of market orientation (Narver et al. 2004; Atuahene-Gima 2005; Tsai et al. 2008; Milfelner 2009; Voola/O'Cass 2010). The vast majority of these studies were conducted outside Europe. They suggest that the two market orientations lead to different consequences, thereby clearly demonstrating the benefit of distinguishing the two forms of market orientation. For example, a proactive market orientation is strongly related to an innovation orientation, new product success (e.g. Narver et al. 2004), the capacity to innovate (Milfelner 2009) and business performance (Voola/O'Cass 2010). None of these studies provides comparisons of market orientation components between groups of managers. 


\section{Key characteristics of European transition economies and Slovenia (in particular) with regard to market orientation}

The problems European transition companies encounter when seeking to adopt Western practices stem from national and organisational cultures (Lang/Steger 2002; Alas/Vadi 2004). Under a communist/socialist regime, there was no need for a market orientation: consumers had little or no choice; managers were primarily concerned with meeting production targets; whether there was a market or not was largely irrelevant; and managers did not expect business performance to be rewarded or penalised. Hence, the transition to a market economy required a fundamental change in managerial attitudes (Ennew et al. 1993; Akimova 2000).

This study focuses on Slovenia, a small transitional economy in South-east Europe. Since its independence in 1991 (after the break-up of former Yugoslavia), Slovenia has been regarded as one of the most successful transitional countries with GDP per capita being substantially higher than in the other new EU member states (Slovenian Business Portal 2011). Among all countries that were formerly under a communist/socialist regime, Slovenia is (according to Inglehart's cultural map) the most similar to Western countries as far as predominant values and lifestyle habits are concerned (Mihelič/Lipičnik 2010). Yet, the historical and economic development of Slovenia within former Yugoslavia heavily influenced marketing developments in Slovenian firms. Most Slovenian firms followed planned production schedules which required the maximum utilisation of production capacity and hence a production orientation dominated during the 1960-1990 period (Makovec Brenčič/Rojšek 2005). After 1991 the business environment of Slovenian firms changed dramatically (i.e. due to the loss of former Yugoslav markets, progressive trade liberalisation, improved supply and import structure), with a market orientation becoming critical to the firms' survival. Nevertheless, two extensive studies of Slovenian companies' market orientation conducted in 1996 and 2001 reveal that »closed « types of orientations still prevailed in Slovenian companies (Snoj/Gabrijan 1998; Snoj et al. 2004). To summarise, the development of a market orientation in Slovenian companies has been a gradual process. Creating a higher level of market orientation remains a challenge for managers.

Although a market orientation only becomes alive when all employees have asked themselves how they contribute to excellence in customer relations and to revenue (e.g. Gummesson 1991), the literature often exposes the critical role of top management in fostering a market orientation, implying that a market orientation originates with top management who are uniquely responsible for fostering customer-oriented values and beliefs (e.g. Kirca et al. 2005; Gebhardt et al. 2006).

According to Nakata (2002), the adoption of a market orientation typically begins at higher levels in the firm, gradually moving down the hierarchy. In 
addition to this pattern of top-down diffusion, Nakata also finds that the understanding of the importance of a market orientation is concentrated in the marketing department. In the case of Slovenian companies, we can assert that both groups of managers understand the importance of being market-oriented. For example, an analysis of mission statements, which serve to communicate firms' fundamental values to their stakeholders, reveals customers as being the most important stakeholder group (Biloslavo 2004). Another study reveals that the majority of Slovenian managers (strongly) agree with the statement that their company puts a firm emphasis on building long-term relationships with the key customers and rank customer satisfaction as the most important measure of business performance (Snoj et al. 2004).

However, general managers and marketing managers may perceive the company's market orientation differently. The limited number of empirical studies that provide comparisons between reports of managers with different managing roles in general find a positive correlation between the responses. However, some studies also indicate that the correlation is not very strong (e.g. Jaworski/Kohli 1993; Pelham 1997). There is a widespread belief in the literature that functional managers selectively perceive organisational competencies in ways that are consistent with their activities and responsibilities (Day/Nedungadi 1994). Marketing managers have presumably more marketing knowledge, are more involved in operative activities related to a market orientation and, due to their closeness to customers, are more informed about markets. Hence, we presume that marketing managers are more critical when they assess how much importance their company attributes to customers and to what extent the company conducts activities that reflect market-oriented behaviours. Further, some authors critically point out that managers may inaccurately perceive their companies as being more market-oriented than their customers do (e.g. Deshpande et al. 2000; Mason/Harris 2005). Importantly, the size of the gap between managers' and customers' perceptions grows as individualism increases (Deshpande et al. 2000). This finding is also relevant in the context of Slovenian managers who are more individualistically- rather than other-oriented (Mihelič/Lipičnik 2010). One of possible reasons for the false perception of managers might be their mistaken assumption of cultural unity (often the culture espoused by top managers) instead of recognising that companies are often a mosaic of subcultures (Mason/Harris 2005). Managers' false perceptions of market orientation could also indicate a lack of touch with the market (Deshpande et al. 1993) which is particularly relevant in the case of Slovenia due to the high number of companies with "closed" business orientations. A market orientation requires the commitment of resources (Kohli/Jaworski 1990); if managers mistakenly believe the company is (highly) market-oriented they might consider that no actions need to be undertaken to improve the market orientation. Since market orientation provides the cultural foundation for organisational learning (Slater/Narver 1995) and innovativeness 
(Hurley/Hult 1998), managers' decisions on efforts to improve the market orientation also hold important implications for the company's ability to develop new knowledge/insights and innovations. Again, since marketing managers are more informed about markets and have more contacts with other employees we assume that their perception of the company's market orientation may be less skewed than the general managers' perceptions.

Table 1 summarises the key thoughts discussed in Section 2, simultaneously providing a framework for our research.

Table 1: Summary of the key thoughts covered in Section 2

\begin{tabular}{|l|l|}
\hline Topic & Key thoughts \\
\hline $\begin{array}{l}\text { The benefit of distinguishing } \\
\text { metween different perspectives on a }\end{array}$ & $\begin{array}{l}\text { Past empirical studies focus on a behavioural and } \\
\text { responsive perspective. However, (1) a market } \\
\text { orientation is essentially a culture that drives the } \\
\text { desired behaviours; and (2) in order to stay } \\
\text { competitive companies should also be proactive, not } \\
\text { only responsively market-oriented. }\end{array}$ \\
\hline $\begin{array}{l}\text { The critical role of top managers } \\
\text { and marketers }\end{array}$ & $\begin{array}{l}\text { The diffusion of a market orientation is typically top- } \\
\text { down and with regard to function areas concentrated } \\
\text { in the marketing department. Hence, top management } \\
\text { and marketers must take the lead in broadening } \\
\text { acceptance of the market orientation within the } \\
\text { organisation. It is therefore important to know how } \\
\text { general managers and marketing managers perceive } \\
\text { their company's market orientation. }\end{array}$ \\
\hline $\begin{array}{l}\text { The managers' perception of } \\
\text { market orientation }\end{array}$ & $\begin{array}{l}\text { General managers and marketing managers may } \\
\text { perceive the company's market orientation differently } \\
\text { due to their different involvement in operative } \\
\text { activities and different closeness/distance to } \\
\text { customers. }\end{array}$ \\
\hline
\end{tabular}

In line with our discussion, we postulate the following main research hypothesis:

H: General managers perceive their companies are more market-oriented (in a cultural and behavioural perspective) than marketing managers do.

\section{Methodology}

The research was conducted in two phases. First, eight in-depth interviews with managers in companies operating in a variety of industries were conducted in order to gain a better understanding of how managers themselves define a market orientation. Second, an Internet survey was conducted among Slovenian companies operating in diverse industries (manufacturing and services). Based on a list of e-addresses of general managers and marketing managers compiled by a call centre at the Slovenian Chamber of Commerce and Industry, each 
manager was sent an email explaining the general purpose of the study and a link to the Internet survey. The explicit term "market orientation" was not used anywhere in the survey. Out of 441 completed questionnaires, yielding a 16 percent response rate, 363 questionnaires completed by general managers and marketing managers were retained for our analysis ${ }^{1}$. In the study sample, $62.3 \%$ of the respondents are general managers and $37.7 \%$ are marketing managers. $52 \%$ of the companies in the study sample are manufacturing and $48 \%$ are service organisations. 54\% of the companies are small (10-49 employees), $31 \%$ of them are medium-sized (50-249 employees), while 15\% are large (more than 250 employees). An early versus late respondent analysis revealed no evidence of non-response bias.

The questionnaire contained 14 items in order to measure the organisational culture, including a market-oriented culture, and 20 items in order to measure responsive and proactive market-oriented behaviour on a seven-point Likert scale ( $1=$ strongly disagree to $7=$ strongly agree). The items were developed based on the literature review of theoretical discussions and existing measures of organisational culture and market orientation, along with the findings from the eight in-depth interviews with managers in the selected companies.

A market-oriented culture was defined as a shared set of values and beliefs which put the customer first (Deshpande et al. 1993). In order to create and deliver superior customer value, which is one of the most important values of a market-oriented company (e.g. Narver/Slater 1990), companies should strive to be better than their competitors (e.g. Kotler 2003) and all employees should work in a co-ordinated way when seeking to satisfy the needs of target customers (e.g. Narver/Slater 1990; Kohli et al. 1993; Homburg/Pflesser 2000). A responsive market orientation was measured based on the widely used MARKOR scale (Kohli et al. 1993) and MKTOR scale (Narver/Slater 1990), whereas a proactive market orientation was measured based on the scale developed by Narver et al. (2004). The findings from the in-depth interviews with managers were also considered in both scales. The questionnaire was pretested with 9 academics and 12 managers.

\section{Results}

First, the measurement model was tested. In addition to responsive and proactive market-oriented behaviours, both the exploratory and confirmatory factor analysis revealed an additional component, i.e. market information. A confirmatory factor analysis using the AMOS 18.0 software indicated the convergent validity of the scales: all latent variables exhibit indices above the

\footnotetext{
${ }^{1}$ The remaining 78 questionnaires were completed by other persons, holding a wide range of positions within the company. This group of informants was asked to self-report a functional position within the company. Many self-reports were incomplete, thus preventing us from clearly defining the hierarchical level of this group of informants.
} 
reference values of the composite reliability index $\left(\rho_{c}\right)$ and the variance extracted $\left(\rho_{\mathrm{v}}\right)$ (see Table 2$)$.

Table 2: Measurement items of a market orientation retained for the analysis

\begin{tabular}{|c|c|}
\hline Items & SFL* \\
\hline \multicolumn{2}{|l|}{ Market-oriented culture $\left(\rho_{\mathrm{c}}=0.77 ; \rho_{\mathrm{v}}=0.53\right)$} \\
\hline $\begin{array}{l}\text { Continuously creating superior customer value relative to competitors is one } \\
\text { of the most important values of our company. }\end{array}$ & 0.75 \\
\hline We constantly consider how to be different and better than competitors. & 0.73 \\
\hline $\begin{array}{l}\text { We believe that only working in a co-ordinated way leads to the better } \\
\text { satisfaction of customer needs relative to our competitors. }\end{array}$ & 0.71 \\
\hline \multicolumn{2}{|l|}{ Market information $\left(\rho_{\mathrm{c}}=0.82 ; \rho_{\mathrm{v}}=0.70\right)$} \\
\hline $\begin{array}{l}\text { We timely recognise changes in the needs, wants and/or buying behaviour of } \\
\text { existing and potential customers. }\end{array}$ & 0.89 \\
\hline We know the customers of our products well. & 0.78 \\
\hline \multicolumn{2}{|l|}{ Responsive market orientation $\left(\rho_{\mathrm{c}}=0.84 ; \rho_{\mathrm{v}}=0.51\right)$} \\
\hline $\begin{array}{l}\text { We respond quickly to changed customer needs, wants and/or buying } \\
\text { behaviour. }\end{array}$ & 0.79 \\
\hline $\begin{array}{l}\text { Business functions work in a co-ordinated way so as to satisfy the needs of } \\
\text { our target markets. }\end{array}$ & 0.79 \\
\hline We respond quickly to competitors' activities. & 0.68 \\
\hline $\begin{array}{l}\text { We adapt the marketing mix (products, prices, distribution, communication) } \\
\text { to selected target markets. }\end{array}$ & 0.66 \\
\hline $\begin{array}{l}\text { In the case of customer dissatisfaction or complaints, we take corrective steps } \\
\text { as fast as possible. }\end{array}$ & 0.64 \\
\hline \multicolumn{2}{|l|}{ Proactive market orientation $\left(\rho_{\mathrm{c}}=0.84 ; \rho_{\mathrm{v}}=0.51\right)$} \\
\hline We examine which needs and wants customers may have in the future. & 0.77 \\
\hline $\begin{array}{l}\text { We try to recognise needs and wants which existing and potential customers } \\
\text { are unaware of or which they do not want to disclose. }\end{array}$ & 0.76 \\
\hline $\begin{array}{l}\text { We examine problems customers may have with existing products in the } \\
\text { market in order to offer a new or better solution to satisfy a need. }\end{array}$ & 0.73 \\
\hline $\begin{array}{l}\text { We work closely with lead customers who recognise their needs months or } \\
\text { years before the majority of potential customers recognise them. }\end{array}$ & 0.66 \\
\hline We develop new products that will satisfy still unexpressed customer needs. & 0.63 \\
\hline
\end{tabular}

*SFL: Standardised Factor Loadings

Model fit: $\quad \chi^{2}=152.2 ; \quad d f=80 ; \quad G F I=0.947 ; \quad N F I=0.943 ; \quad T L I=0.963 ; \quad C F I=0.972 ;$ RMSEA $=0.050$ 
For every pair of constructs, the unconstrained model was compared with the constrained model in which the correlation between two constructs was set to 1 . For each pair of constructs, the chi-square difference between the unconstrained model and the constrained model was statistically significant $\left(\Delta \chi^{2}>3.84\right)$, thereby supporting the presence of the discriminant validity of our constructs.

As Table 3 shows, for the whole sample the mean score of a market-oriented culture is significantly higher than the mean scores of all three behavioural dimensions and the mean score of a proactive market orientation is significantly lower than the mean scores of market information and a responsive market orientation. No significant differences were found in the mean scores of the market orientation components given the company size or the main business sector (manufacturing vs. service organisations).

Table 3: Means and standard deviations (SD)

\begin{tabular}{|l|l|l|l|}
\hline Variables & $\begin{array}{l}\text { Mean } \\
(\mathrm{n}=363)\end{array}$ & SD & $\begin{array}{l}\text { 95\% Confidence Interval for } \\
\text { Mean }\end{array}$ \\
\hline Market-oriented culture & 5.84 & 1.09 & $5.73-5.95$ \\
\hline Market information & 5.35 & 1.06 & $5.25-5.46$ \\
\hline Responsive market orientation & 5.32 & 1.03 & $5.21-5.42$ \\
\hline Proactive market orientation & 4.97 & 1.10 & $4.86-5.08$ \\
\hline
\end{tabular}

Table 4 shows that the correlations between all market orientation components are strong, ranging from 0.52 to 0.69 . Additional analysis reveals that all correlations between the market orientation components are slightly stronger in the group of marketing managers. However, the differences between both groups of managers are not statistically significant.

Table 4: Pearson's correlation coefficients

\begin{tabular}{|l|c|c|c|c|}
\hline & $\begin{array}{l}\text { Market-oriented } \\
\text { culture }\end{array}$ & $\begin{array}{l}\text { Market } \\
\text { information }\end{array}$ & $\begin{array}{l}\text { Responsive } \\
\text { market } \\
\text { orientation }\end{array}$ & $\begin{array}{l}\text { Proactive } \\
\text { market } \\
\text { orientation }\end{array}$ \\
\hline $\begin{array}{l}\text { Market- } \\
\text { oriented culture }\end{array}$ & 1.000 & $0.523^{* *}$ & $0.625^{* *}$ & $0.623^{* *}$ \\
\hline $\begin{array}{l}\text { Market } \\
\text { information }\end{array}$ & 1.000 & $0.611^{* *}$ & $0.558^{* *}$ \\
\hline $\begin{array}{l}\text { Responsive } \\
\text { market } \\
\text { orientation }\end{array}$ & & & 1.000 & $0.687^{* *}$ \\
\hline $\begin{array}{l}\text { Proactive } \\
\text { market } \\
\text { orientation }\end{array}$ & & & & 1.000 \\
\hline
\end{tabular}

Note: ** Significant at the 0.01 level 
It should be noted that there are no significant differences between the structure of both groups of managers given the company size and main business sector. Thus, no systematic error was found in the subsample structure in relation to the main company characteristics. In addition, there are no significant differences in the mean scores of the market orientation components within each group of managers given the company size and main business sector. In other words, the general managers' perceptions of market orientation do not differ significantly between larger and smaller companies (or between production and service companies). Similarly, no such differences were revealed within the group of marketing managers.

Comparisons of market orientation components' perceptions between the two groups of managers were conducted by testing for invariant latent mean structures. Following Byrne (2001) and Hair et al. (2005), first a confirmatory factor analysis was applied to the same measurement model in each group separately. In the second step, a confirmatory factor analysis was applied in both groups simultaneously in order to test a factor's structure equivalence. Finally, the equivalence of factor loadings, variances and covariances was tested.

Once the metric invariance was established, we tested for latent mean differences between both groups of managers ${ }^{1}$. In the structural equation model, the output provides only one set of means representing the difference between group means (Hair et al. 2005). The results are therefore interpreted in a relative sense: the positive standardised mean in Table 5 indicates a better assessment of market orientation among the group of general managers compared to the group of marketing managers. The difference is significant where $|t|>1.96$. As Table 5 shows, in support of our research hypothesis the general managers assessed all four dimensions of a market orientation (i.e. a market-oriented culture, market information, a responsive and a proactive market orientation) significantly better than the marketing managers.

\footnotetext{
${ }^{2}$ The procedure includes programming the structured means model for each group of managers and introducing several constraints (e.g. all factor loadings, except for those fixed to 1.00, and all intercepts for the observed measures are constrained equal across groups). The four factor means are freely estimated for the group of general managers, but constrained equal to zero for the group of marketing managers. The latter group is therefore regarded as the reference group. A determination of which group should serve as the reference group is arbitrary. For more details on testing for invariant latent mean structures, see Byrne (2001).
} 
Table 5: Results of the two-group analysis

\begin{tabular}{|c|c|c|c|c|c|c|c|c|c|c|}
\hline \multirow[t]{2}{*}{$\begin{array}{l}\text { Groups of } \\
\text { informants }\end{array}$} & \multicolumn{2}{|c|}{ Model fit } & \multicolumn{2}{|c|}{$\begin{array}{l}\text { Market- } \\
\text { oriented } \\
\text { culture }\end{array}$} & \multicolumn{2}{|c|}{$\begin{array}{l}\text { Market } \\
\text { information }\end{array}$} & \multicolumn{2}{|c|}{$\begin{array}{l}\text { Responsive } \\
\text { market } \\
\text { orientation }\end{array}$} & \multicolumn{2}{|c|}{$\begin{array}{l}\text { Proactive } \\
\text { market } \\
\text { orientation }\end{array}$} \\
\hline & CFI & RMSEA & Mean $^{\mathrm{a}}$ & $t^{*}$ & Mean & $\mathrm{t}$ & Mean & $\mathrm{t}$ & Mean & $\mathrm{t}$ \\
\hline $\begin{array}{l}\text { General } \\
\text { managers }\end{array}$ & 0.96 & 0.037 & 0.32 & 2.45 & 0.41 & 3.36 & 0.52 & 4.04 & 0.38 & 3.08 \\
\hline $\begin{array}{l}\text { Marketing } \\
\text { managers }\end{array}$ & & & & & & & & & & \\
\hline
\end{tabular}

Notes: ${ }^{a}$ Mean $=$ standardised mean

* Significant at $p<0.05$, if $|t|>1.96$

In addition, t-tests within smaller (10-49 employees) and larger companies (at least 50 employees) also reveal that the general managers perceive the company's market orientation significantly better than the marketing managers within each group of companies. Further, t-tests of single items reveal that, with regard to a market-oriented culture, general managers significantly more agree that continuously creating superior value to competitors is one of the most important values of the company and that the company believes that only working in a co-ordinated way leads to the better satisfaction of customer needs. In addition, general managers significantly better assessed the company's capability to timely recognise market changes as well as having good knowledge about the company's customers. With regard to responsive and proactive behaviours, the general managers significantly more than the marketing managers believe that their companies quickly respond to market changes; business functions work in a co-ordinated way so as to satisfy the target markets; the company adapts the marketing mix to selected target markets; the company tries to recognise unexpressed customer needs and examine problems customers may have, and that the company works closely with lead customers $(\mathrm{p}<0.05)$.

It is worth mentioning that our questionnaire also contained a few items reflecting other corporate culture characteristics, such as innovativeness. Hence, additional comparisons between managers' responses were made. Similar to our finding related to a market orientation, general managers express a stronger agreement that ideas which depart from existing thinking are welcome in the company; the company encourages creativity and innovativeness at all levels, and rewards employees for their good ideas $(\mathrm{p}<0.05)$.

\section{Discussion and conclusion}

Our study focused on managers' perceptions of their company's market-oriented culture and behaviours at two hierarchical levels: general managers vs. 
marketing managers. The analysis of responses obtained from managers in 363 Slovenian companies revealed that the general managers on average significantly better perceived all four market orientation components (i.e. a market-oriented culture, market information, responsive and proactive marketoriented behaviour) than the marketing managers. A possible explanation of the significant differences across both groups of managers is that the responses of the general managers might reflect more of the desired situation (how it should be in the company, whereas the responses of the marketing managers might more strongly reflect the actual situation as perceived by those managers). We can reasonably assume that marketing managers are, due to their greater marketing knowledge and involvement in operative work, more critical when it comes to assessing their company's market orientation. Conversely, the general managers' more favourable perceptions might reflect their mistaken assumption of cultural unity (Ogbonna/Harris, 1998; Mason/Harris 2005). In this vein, Slovenian general managers may believe that the understanding of the importance is spread across the whole organisation. The existence of differences in the mean scores of the managers at two hierarchical levels indicates that an even greater discrepancy among employees' responses may exist at lower hierarchical levels. As the literature suggests, the cultural and operational adoption of a market orientation is presumably less intense for those functional areas most removed from customers (Gonzalez-Benito/Gonzalez-Benito 2005), e.g. production, $R \& D$ or the finance department. However, due to the singleinformant approach our study should be viewed as explorative research and hence our conclusions should be treated with caution.

Further, our study reveals that all market orientation components are strongly correlated. However, the cultural adoption is, on average, significantly higher than the behavioural adoption of a market orientation, implying there is a gap between what managers perceive as important in the company and how they perceive the company's activities related to a market orientation. This finding is in line with some previous studies that also found a discrepancy between values and actions (e.g. Diamantopoulos/Hart 1993; Gonzalez-Benito/Gonzalez-Benito 2005), suggesting that a market-oriented culture is not fully implemented through market-oriented behaviours. In addition, a proactive market orientation is on average significantly less developed than the other components of a market orientation.

Our study has important practical implications. Managers' perceptions of their company's market orientation effect managerial decision-making. As the literature suggests, managerial decision-making is largely subjective, being dependent on the mental modes of the particular decision-making situation (Day/Nedungadi 1994). Since Slovenian general managers better perceive their company's market orientation they might also perceive that, in comparison to marketing managers, relatively fewer additional resources and efforts should be required to bring about improvements in the company's market orientation. 
Hence, marketing managers will have to convince general managers that the company needs a relatively stronger improvement in their company's market orientation. Their success in doing this may largely depend on the role of the marketing function within the company. As Verhoef and Leeflang (2009) assert, both the marketing department's perceived influence and top management's respect for the marketing department are positively related to a market orientation. Žabkar and Zbačnik (2006) found that in the majority of Slovenian companies marketing plays an important role. We believe that marketers in these companies are in a better position to persuade general managers to invest more resources in improving the company's market orientation.

As Hunt and Morgan (1995) state, a market orientation can only be a source of comparative advantage if it is rare among the competitors. Hence, a company should constantly strive to develop a higher level of market orientation relative to its competitors. A higher market orientation will positively impact organisational learning (Slater/Narver 1995) and innovativeness (Hurley/Hult 1998). The literature strongly emphasises that a market orientation should underlie the whole organisation (e.g. Gummesson 1991). In order to boost the level of a company's market orientation Slovenian top managers need to clearly communicate the values that support a market-oriented culture and act in line with their beliefs. Narver et al. (1998) suggest two approaches to developing a market-oriented culture. In the first, more commonly used approach, the company provides education programmes to teach individuals about the nature and importance of a market orientation and the basic processes and skills of creating superior value for the customer. A second approach is an experiential approach in which employees continuously learn from the company's day-today efforts to create and maintain superior value for customers and thereby continuously develop and adapt skills and procedures related to a market orientation. It is important that the company employs both approaches because the mere use of educational programmes is insufficient (Narver et al. 1998). The latter is particularly relevant for Slovenian companies because previous research suggest that only $19 \%$ of employees in Slovenia follow their superior's instructions without questioning them (Borgulya/Hahn 2008).

At the same time, the company should establish a management information system to gather, process and disseminate needed, timely and accurate information which enables managers to more accurately perceive the company's market orientation and hence make better business decisions. As previous studies suggest, Slovenian companies gather market information, yet they retain it in a limited circle which constrains effective decision-making (e.g. Mumel/Iršič 1998). Snoj et al. (2004) report that more than 50\% of Slovenian managers believe that their company's competitive advantages are a good understanding of customer needs and relationships with key target customers. However, only $36 \%$ of managers believe that their company uses market information better than competitors. In addition, only $16 \%$ believe that their 
information system is significantly better developed than the competitors. Better market intelligence can be developed through the use of customer relationship management which enables the company to build a deeper understanding of its customers and develop stronger bonds with them.

Our study reveals that market information is correlated strongly to responsive and proactive market-oriented behaviours. By improving market information companies can therefore increase the level of a responsive and a proactive market orientation. In particular, Slovenian companies should increase the level of their proactive market orientation which is significantly less developed than the other components of a market orientation. In a dynamic environment only responding to expressed customer needs is insufficient to sustain a competitive advantage (e.g. Narver et al. 2004). Companies can increase their proactive market orientation by examining latent and future customer needs, examining problems customers may have when seeking to satisfy their needs, working closely with lead customers and developing new products that will satisfy hitherto unexpressed customer needs.

This study contributes to the existing market orientation literature since it is the first study to explicitly examine differences in managers' responses by distinguishing between the cultural and behavioural perspective and between a responsive and a proactive market orientation. A review of 125 empirical studies revealed that almost $95 \%$ of the studies used market orientation scales with a behavioural emphasis, whereas less than $5 \%$ of the studies simultaneously considered both a cultural and a behavioural perspective (GonzalezBenito/Gonzalez-Benito 2005). Distinguishing between different layers of a market orientation can help managers better understand the presence of a firm's market orientation as a culture and as behaviours as well as antecedents of market-oriented behaviour within an organisation. As Narver et al. (1998) point out, market oriented behaviours will not endure unless the desired commitments and behaviours emanate from the organisation's culture. Hence, the market orientation should first and foremost be understood as an organisation's culture and not merely as a set of activities (Narver et al. 1998). In addition, although it is important to create the customer not just serve the customer (e.g. Hame1/Prahalad 1991; Christensen/Bower 1996), only very few studies to date have adopted both forms of market orientation, i.e. responsive and proactive. The vast majority of these studies were conducted outside Europe. By simultaneously adopting different perspectives on market orientation (i.e. cultural/behavioural; responsive/proactive) on a sample of Slovenian companies, this study contributes to the limited knowledge on the development of a market orientation in CEE countries. Importantly, despite the need for studies which compare perceptions of employees at different levels (Jaworski/Kohli 1993) such research has so far been very limited. Our study is the first that compares perceptions between general managers and marketing managers. The comparison was made by testing for invariant latent mean structures. According 
to Byrne (2001) there is a dearth of studies involving multi-group comparisons of latent mean structures.

This study also has several limitations. First, similar to the vast majority of marketing research our study used a single informant per unit of analysis. It is often difficult to know whether a single individual in a complex organisation can provide valid information (Anderson 1985). Key informant reports should therefore be validated by the reports of other informants to reduce the functional position effects within the organisation and to develop reliable measures of constructs (e.g. Deshpande et al. 1993; Harris 2002). In particular, when examining the differences between managers' responses a multi-informant research design would yield a more valid conclusion. Second, in our study managers were divided into two groups based on their hierarchical level. In future research, it is recommended to apply additional measures to further assess the qualifications of the informants, e.g. the number of years the informant has worked in the company and the extent to which the informant has participated in company decision-making with respect to issues covered in the survey (Phillips 1981).

Third, some authors believe that the evaluation of the company's market orientation should come from its customers rather than merely from the company itself (Deshpande et al. 1993). The few studies that have compared managers' self-reports with customer reports reveal that the suppliers had better perceptions of the company's market orientation than their customers (e.g. Deshpande et al. 2000). It is apparent that the bigger the gap in perceived market orientation between the supplier and the buyer, the lower the customer satisfaction (Krepapa et al. 2003).

Fourth, building on the existing literature, Slovenian managers are recommended to invest resources in increasing the level of their company's proactive market orientation. However, a proactive market orientation may be more important for innovators and early adopters but less so for late majorities and laggards (Menguc/Auh 2006). In other words, a company might be proactive only in certain markets and/or product categories. Further, our study sample consists of firms operating in diverse industries. It should be noted that there are no significant differences in the mean scores of the market orientation components given the main business sector and the company size, and no systematic error was found in the structure of both groups of managers given the main company characteristics. Nevertheless, focusing on a single industry or even a single company could provide a much better insight into the creation of a market orientation in a specific context. Finally, scholars have so far focused on the achieved market orientation level. In contrast, Song and Parry (2009) focus on the desired level of a market orientation, which can be defined as the market orientation level managers believe will maximise the business performance. 
Their empirical study suggests that the desired level of a market orientation positively influences the level actually achieved.

To conclude, in future research it is suggested to make comparisons of different market orientation components: (1) across managers, employees at lower hierarchical levels and customers by adopting a multi-informant approach; (2) with respect to different markets and/or product categories; and (3) between the achieved and desired level of market orientation components.

\section{References}

Anderson, J.C. (1985): A measurement model to assess measure-specific factors in multipleinformant research, in: Journal of Marketing Research, 22, 1, 86-92.

Akimova, I. (2000): Development of market orientation and competitiveness of Ukrainian firms, in: European Journal of Marketing, 34, 9/10, 1128-1148.

Alas, R./Vadi, M. (2004): The impact of organisational culture on attitudes concerning change in post-soviet organisations, in: Journal for East European Management Studies, 9, 1, 20-39.

Atuahene-Gima, K./Slater, S.F./Olson, E.M. (2005): The contingent value of responsive and proactive market orientations for new product program performance, in: Journal of Product Innovation Management, 22, 6, 464-482.

Biloslavo, R. (2004): Web-based mission statements in Slovenian enterprises, in: Journal for East European Management Studies, 9, 3, 265-277.

Borgulya, A./Hahn, J. (2008): Work related values and attitudes on Central and Eastern Europe, in: Journal for East European Management Studies, 13, 3, 216-238.

Byrne, B. M. (2001): Structural equation modeling with AMOS: basic concepts, applications, and programming. New Jersey: Lawrence Erlbaum Associates, Inc.

Catana, G.A./Catana, D. (2004): Marketing strategies for Central and Eastern Europe, in: Journal for East European Management Studies, 9, 3, 328-333.

Christensen, C.M./Bower, J. L. (1996): Customer power, strategic investment, and the failure of leading firms, in: Strategic Management Journal, 17, 3, 197-218.

Conrad, C.A. (1999): Market orientation and the innovative culture: a preliminary empirical examination, in: Journal of Strategic Marketing, 7, 4, 229-236.

Day, G.S. (1999): Misconceptions about market orientation, in: Journal of Market-Focused Management, 4, 5-16.

Day, G.S./Nedungadi, P. (1994): Managerial representation of competitive advantage, in: Journal of Marketing, 48, 2, 31-44.

Deshpande, R./Farley, J.U./Webster, F.E.Jr. (1993): Corporate culture, customer orientation, and innovativeness in Japanese firms: a quadrad analysis, in: Journal of Marketing, 57, $1,23-27$.

Deshpande, R./Farley, J.U./Webster, F.E.Jr. (2000): Triad lessons: generalizing results on high performance firms in five business-to-business markets, in: International Research in Marketing, 17, 4, 353-362. 
Diamantopoulos, A./Hart, S. (1993): Linking market orientation and company performance: preliminary evidence on Kohli and Jaworski's framework, in: Journal of Strategic Marketing, 1, 2, 92-121.

Ellis, P.D. (2006): Market orientation and performance: a meta-analysis and cross-national comparisons, in: Journal of Management Studies, 43, 5, 1089-1107.

Ennew, C.T./Filatotchev, I./Wright, M./Buck, T.W. (1993): Constraints on the adoption of the marketing concept: The case of former Soviet Union, in: European Journal of Marketing, 27, 11/12, 21-34.

Gebhardt, G.F./Carpenter, G.S./Sherry, J.F. (2006): Creating a market orientation: a longitudinal, multifirm, grounded analysis of cultural transformation, in: Journal of Marketing, 70, 4, 37-55.

Golden, P.A./Doney, P.M./Johnson, D.M./Smith, J.S. (1995): The dynamics of a marketing orientation in transition economies: A study of Russian firms, in: Journal of International Marketing, 3, 2, 29-49.

Gonzalez-Benito, O./Gonzalez-Benito, J. (2005): Cultural vs. operational market orientation and objective vs. subjective performance: perspective of production and operations, in: Industrial Marketing Management, 34, 8, 797-829.

Gummesson, E. (1991): Marketing-orientation revisited: the crucial role of the part-time marketer, in: European Journal of Marketing, 25, 2, 60-75.

Hair, J.F.Jr./Black, W.C./Babin, B.J./Anderson, R.E./Tatham, R.L. (2005): Multivariate data analysis. Upper Saddle River: Pearson Prentice Hall.

Hamel, G./Prahalad, C.K. (1991): Corporate imagination and expeditionary marketing, in: Harvard Business Review, 69, 4, 81-92.

Harris, L. (2002): Measuring market-orientation: exploring a market oriented approach, in: Journal of Market-Focused Management, 5, 3, 239-270.

Homburg, C./Pflesser, C. (2000): A multiple-layer model of market-oriented organizational culture: measurement issues and performance outcomes, in: Journal of Marketing Research, 37, 4, 449-462.

Hooley, G./Cox, T./Fahy, J./Shipley, D./Beracs, J./Fonfara, K./Snoj, B. (2000): Market orientation in the transition economies of central Europe: tests of the Narver and Slater market orientation scales, in: Journal of Business Research, 50, 3, 273-285.

Hult, G.T.M./Ketchen, D.J. (2001): Does market orientation matter? A test of the relationship between positional advantage and performance, in: Strategic Management Journal, 22, 9, 899-906.

Hult, G.T.M./ Ketchen, D.J./Slater SF (2005): Market orientation and performance: An integration of disparate approaches, in: Strategic Management Journal, 26, 12, 11731181 .

Hunt, S.D./Morgan, R.M. (1995): The comparative advantage theory of competition, in: Journal of Marketing, 59, 2, 1-15.

Hurley, R.F./ Hult, G.T.M. (1998): Innovation, market orientation, and organizational learning: An integration and empirical examination, in: Journal of Marketing, 62, 3, 42-54. 
Jaworski, B.J./Kohli, A. K. (1993): Market orientation: antecedents and consequences, in: Journal of Marketing, 57, 3, 53-70.

Kirca, A.H./Jayachandran, S./Bearden, W.O. (2005): Market orientation: a meta-analytic review and assessment of its antecedents and impact on performance, in: Journal of Marketing, 69, 2, 24-41.

Kohli, A.K./Jaworski, B.J. (1990): Market orientation: The construct, research propositions, and managerial implications, in: Journal of Marketing, 54, 2, 1-18.

Kohli, A.K./Jaworski, B.J./Kumar, A. (1993): MARKOR: a measure of market orientation, in: Journal of Marketing Research, 30, 4, 467-477.

Kotler, P. (2003): Marketing management, $11^{\text {th }}$ edition, Prentice Hall.

Krepapa, A./Berthon, P./Webb, D./Pitt, L. (2003): Mind the gap: an analysis of service provider versus customer perceptions of market orientation and the impact on satisfaction, in: European Journal of Marketing, 37, 1/2, 197-218.

Lang, R./Steger, T. (2002): The odyssey to management knowledge to transforming societies: a critical review of a theoretical alternative, in: Human Resource Development International, 5, 3, 279-294.

Makovec Brenčič, M./Rojšek, I. (2005): Marketing in Slovenia: Changes and challenges, in: M. Marinov (ed.): Marketing in the emerging markets of Central and Eastern Europe, Palgrave Macmillan, 128-152.

Mason, K./Harris, L.C. (2005): Pitfalls in evaluating market orientation: an exploration of executives' interpretations, in: Long Range Planning, 38, 4, 373-391.

Menguc, B./Auh, S. (2006): Creating a firm-level dynamic capability through capitalizing on market orientation and innovativeness, in: Journal of the Academy of Marketing Science, 34, 1, 63-73.

Mihelič, K.K./Lipičnik, B. (2010): Corporate managers and their potential younger successors: an examination of their values, in: Journal for East European Management Studies, 15, 4, 288-311.

Milfelner, B. (2009): The role of proactive and responsive market orientation in the development of a firm's innovation resources, in: Naše gospodarstvo, 55, 1/2, 51-58.

Mumel, D./Iršič, M. (1998): Ali razlike v tipu lastništva podjetij odsevajo tudi v menedžmentu njihovih marketinških aktivnosti? Primerjalna analiza Slovenije in Madžarske. In: Akademija MM, 3, 69-74.

Nakata, C. (2002): Activating the marketing concept in a global context, in: International Marketing Review, 19, 1, 39-64.

Narver, J.C./Slater, S.F. (1990): The effect of a market orientation on business profitability, in: Journal of Marketing, 54, 4, 20-35.

Narver, J.C./Slater, S.F./MacLachlan, D. L. (2004): Responsive and proactive market orientation and new-product success, in: Journal of Product Innovation Management, $21,5,334-347$.

Narver, J.C./Slater, S.F./Tietje, B. (1998): Creating a market orientation, in: Journal of Market-Focused Management, 2, 3, 241-255. 
Ogbonna, E./Harris, L.C. (1998): Managing organizational culture: compliance or genuine change? In: British Journal of Management, 9, 273-288.

Pelham, A. M. (1997): Mediating influences on the relationship between market orientation and profitability in small industrial firms, in: Journal of Marketing Theory and Practice, 5, 3, 55-76.

Phillips, L.W. (1981): Assessing measurement error in key informant reports: a methodological note on organizational analysis in marketing, in: Journal of Marketing Research, 18, 4, 395-415.

Sheth, J.N./Sisodia, R.S. (1999): Revisiting marketing's lawlike generalizations, in: Journal of the Academy of Marketing Science, 27, 1, 71-87.

Slater, S.F./Narver, J.C. (1995): Market orientation and the learning organization, in: Journal of Marketing, 59, 3, 63-74.

Slater, S.F./Narver, J.C. (1998): Research notes and communications: market-oriented is more than being customer-led: let's not confuse the two, in: Strategic Management Journal, $19,10,1001-1006$.

Slovenian Business Portal (2011): www.poslovniportal.si

Snoj, B./Gabrijan, V. (1998): Tržna naravnanost podjetij v Sloveniji - realnost ali fikcija? In: Akademija MM, 2, 9-14.

Snoj, B./Gabrijan, V./Mumel, D./Pisnik-Korda, A./ Petejan, A. (2004): Tržni vidiki konkurenčnih sposobnosti podjetij v Sloveniji. Maribor: Ekonomsko-poslovna fakulteta.

Song, M./Parry, M.E. (2009): The desired level of market orientation and business unit performance, in: Journal of the Academy of Marketing Science, 37, 2, 144-160.

Tsai, K./Chou, C./Kuo, J. (2008): The curvilinear relationships between responsive and proactive market orientations and new product performance: a contingent link, in: Industrial Marketing Management, 37, 8, 884-894.

Van Raaij, E.M./Stoelhorst, J.W. (2008): The implementation of a market orientation: A review and integration of the contributions to date, in: European Journal of Marketing, $42,11 / 12,1265-1293$.

Verhoef, P.C./Leeflang, P.S.H. (2009): Understanding the marketing department's influence within the firm, in: Journal of Marketing, 73, 2, 14-37.

Voola, R./O'Cass, A. (2010): Implementing competitive strategies: the role of responsive and proactive market orientations, in: European Journal of Marketing, 44, 1/2, 245-266.

Žabkar, V./Zbačnik, B. (2006): Marginalizacija trženja? Ne povsod! In: Manager+, 3, 15-17. 